\title{
Parasitoid complex (Hymenoptera: Eulophidae) of the leaf-mining fly Chromatomyia horticola (Goureau) (Diptera: Agromyzidae) in Russia
}

\author{
Zoya Yefremova • I. Strakhova • V. Kravchenko • \\ M. von Tschirnhaus $\cdot$ E. Yegorenkova
}

Received: 4 November 2013 / Accepted: 3 July 2014 / Published online: 15 July 2014

(C) The Author(s) 2014. This article is published with open access at Springerlink.com

\begin{abstract}
Sixteen species of Eulophidae were reared from Chromatomyia horticola (Goureau) collected from 14 host plants in the Middle Volga Basin (Russia). Chrysocharis viridis (Nees), Closterocerus trifasciatus Westwood, Diglyphus pusztensis (Erdös), Minotetrastichus frontalis (Nees), Neochrysocharis aratus (Walker), Pediobius cassidae Erdös, and Pnigalio pectinicornis (Linnaeus) are new host records. Two parasitic species, D. isaea (Walker) and P. metallicus (Nees), were dominant. The pre-imaginal
\end{abstract}

Z. Yefremova $(\bowtie) \cdot V$. Kravchenko

Department of Zoology, The George S. Wise Faculty of Life

Sciences, Tel-Aviv University,

Tel-Aviv 69978, Israel

e-mail: eulophids@mail.ru

V. Kravchenko

e-mail: vasiliy1953@yandex.ru

Z. Yefremova $\cdot$ I. Strakhova

Department of Zoology, Ulyanovsk State Pedagogical

University,

Ulyanovsk 432700, Russia

I. Strakhova

e-mail: istra@bk.ru

M. von Tschirnhaus

Faculty of Biology, University of Bielefeld,

Bielefeld, Germany

e-mail: m.tschirnhaus@uni-bielefeld.de

E. Yegorenkova

Department of Geography, Ulyanovsk State Pedagogical

University,

Ulyanovsk 432700, Russia

e-mail: Egorenkova80@mail.ru stages of both dominant (ecto- and endoparasitoid) species are illustrated. The sex ratio between the ecto- and endoparasitoids differed. In June/July, there were about threefold more females in ectoparasitoids than in endoparasitoids. These differences in sex ratio were not related to the plant species only. The endoparasitoid species were found on all species of host plants of C. horticola, whereas the ectoparasitoid species were restricted to about half the plant species. Diglyphus isaea and Pediobius metallicus are very important regulating species against leaf miner pests such as C. horticola.

Keywords Chalcidoidea - Garden pea leaf-miner . Spontaneous grass plants

\section{Introduction}

The leaf-miner agromyzid fly Chromatomyia horticola (Goureau 1851) has a cosmopolitan range of distribution, damaging crops and ornamental plants in many countries throughout the world (Anon. 1987; Dempewolf 2006; Spencer 1973; von Tschirnhaus 1969). It has highly polyphagous larvae and although listed to date by Benavent-Corai et al. (2005) from 230 species of the dicot and monocot genera of herbaceous plants, many additional plants do not appear on the list. Spencer (1990) presented a Table of 35 host plant families. Hosts in the Brassicaceae, Fabaceae and Asteraceae are dominant for C. horticola (Spencer 1973, 1976, 1989, 1990; Raj et al. 1995). The larval 
instars of C. horticola were described by Melis (1935) [as Phytomyza atricornis Meig., cf. Griffiths 1967:1-2], and further morphological characters also by Cohen (1936) and Allen (1958) (as P. atricornis, both could possibly also refer to the sibling species $C$. syngenesiae Hardy, cf. Griffiths 1967), as well as by M. Dempewolf (2001, Dissertation, Univ. Bielefeld, Germany). The species pupates internally at the end of the mine, with the anterior spiracles of the whitish puparium projecting through the plant epidermis (Spencer 1976). The whitish mine is linear or serpentine on both the upper and lower surface of the leaf.

In Europe and western Turkey the complex of parasitoids reared from $C$. horticola comprises 21 species of Eulophidae (Table 1). Species composition presents six species of Chrysocharis [Ch. entedonoides (Walker), Ch. gemma (Walker), Ch. nephereus (Walker), Ch. orbicularis (Nees), Ch. pentheus (Walker), Ch. pubicornis (Zetterstedt) (Hansson 1985; Rizzo \& Massa 2002, 2004; Vidal 1997)]; six species of Diglyphus [D. crassinervis Erdös (Erdös 1958), D. chabrias (Walker) (Yefremova et al. 2011), D. isaea (Walker) (del Bene et al. 1993; Gençer 2005; Kumar 1985), Diglyphus minoeus (Walker), D. pachyneurus Graham (Gençer 2005), D. poppoea Walker (Rizzo \& Massa 2002)]; and 2 species of Cirrospilus [C. vittatus Walker (del Bene 1989) and C. variegatus (Masi) (Rizzo \& Massa 2002, 2004)] Hemiptarsenus ornatus (Nees) (del Bene 1989; Rizzo \& Massa 2002), Neochrysocharis formosus (Westwood) (del Bene 1989; Rizzo \& Massa 2002), Omphale stigma Goureau (Goureau 1851), Pnigalio soemius Walker, P. incompletus Bouček (Rizzo \& Massa 2002), Pediobius metallicus (Nees) (Bouček, 1965; del Bene 1989; Civelek 2002; Gençer 2005; Rizzo \& Massa 2002), Semielacher petiolata Girault (Massa et al. 2001; Rizzo \& Massa 2002). The parasitoid complexes of 15 species of Agromyzidae (including C. horticola) from the Middle Volga Basin were recently studied (Strakhova et al. 2013; Yefremova et al. 2012).

Taxonomically, we concur with the generic transfer of all world Chromatomyia Hardy, 1849 species to the genus Phytomyza Fallén, 1810, as recently published by Winkler et al. (2009). Without the provision of a detailed discussion of the male genitalia, the larval morphology, the specific mode of pupation, and the extensive published discussions and opinions on the generic/subgeneric status, the synonymization of Chromatomyia (so widely used in the multilingual agricultural world literature, including handbooks) all remains highly puzzling for taxonomists and applied entomologists.

The aim of the present work was to document the parasitoid complex of $C$. horticola. This paper, which summarizes our original data and earlier published information on the eulophid species, seeks to uncover the relationships between species composition of parasitoids, C. horticola, and its host plants, and to analyze the ratio of ecto- and endoparasitoids of C. horticola, with emphasis on their development in the puparium.

\section{Materials and methods}

The study was conducted in three adjacent locations in the Middle Volga Basin (Russia): (i) Ulyanovsk, left bank of the River Volga, Park $\left(54^{\circ} 22^{\prime} \mathrm{N}, 48^{\circ} 32^{\prime} \mathrm{E}\right)$, (ii) Ulyanovsk Province, Dimitrovgrad $\left(54^{\circ} 13^{\prime} \mathrm{N}, 49^{\circ} 36^{\prime} \mathrm{E}\right)$, and (iii) Ulyanovsk Province, village Lebjazhye, $90 \mathrm{~km}$ E of Ulyanovsk $\left(54^{\circ} 06^{\prime} \mathrm{N}, 49^{\circ} 36^{\prime} \mathrm{E}\right)$.

Chromatomyia horticola mines appeared from the end of April until September in a temperate zone in Russia, with a maximum number in July, which is the warmest summer month in the study area. Leaves with C. horticola mines were collected from ruderal herbaceous plants near roads, in gardens, and parks from May to September 2010. This period corresponds to the seasonal peak in Agromyzidae activity, with highest growth of their host plants and highest species richness of insects in general.

Leaves were collected every 3 days from the same territory. Typical mines of $C$. horticola on leaves of white ox-eye daisy, chickory lettuce, hollyhock, and dandelion are illustrated in Figures 14. The collected leaves with larvae were kept in the laboratory in 0.25 -liter containers under room temperature of $20-22^{\circ} \mathrm{C}$. Individuals emerging from C. horticola mines in the containers were collected using a pooter and immersed in $75 \%$ ethanol prior to mounting and identification.

Samples were sorted using a stereomicroscope MC-2 ZOOM, and photographed using Canon Power Shot A 640. The reared Eulophidae were identified by the Russian authors. Identification keys for Diglyphus species are available for Europe (Yefremova \& Shroll 1996), for Chrysocharis 
Table 1 Parasitoid species reared from Chromatomyia horticola mines by different authors during 1958-2011.

\begin{tabular}{|c|c|c|c|}
\hline Parasitoid species & Ecto/endo parasitoids & Authors & Country \\
\hline Chrysocharis pentheus (Walker) & endo & $\begin{array}{l}\text { Hansson } 1985 \\
\text { Ikeda } 1996 \\
\text { Vidal } 1997 \\
\text { Gençer } 2009 \\
\text { Rizzo \& Massa } 2002\end{array}$ & $\begin{array}{l}\text { Sweden } \\
\text { Japan } \\
\text { Germany } \\
\text { Turkey } \\
\text { Italy }\end{array}$ \\
\hline Chrysocharis pubicornis (Zetterstedt) & endo & $\begin{array}{l}\text { Rizzo \& Massa } 2002 \\
\text { Gençer } 2009 \\
\text { Vidal } 1997 \\
\text { Ikeda } 1996\end{array}$ & $\begin{array}{l}\text { Italy } \\
\text { Turkey } \\
\text { Germany } \\
\text { Japan }\end{array}$ \\
\hline Cirrospilus vittatus Walker & ecto & del Bene 1989 & Italy \\
\hline Diglyphus crassinervis Erdös & ecto & Erdös 1958 & Hungary \\
\hline Diglyphus isaea (Walker) & ecto & $\begin{array}{l}\text { Kumar } 1985 \\
\text { del Bene et al. } 1993 \\
\text { Gençer } 2005\end{array}$ & $\begin{array}{l}\text { India } \\
\text { Italy } \\
\text { Turkey }\end{array}$ \\
\hline Diglyphus chabrias (Walker) & ecto & Yefremova et al. 2011 & Turkey \\
\hline Diglyphus pachyneurus Graham & ecto & Gençer 2005 & Turkey \\
\hline Chrysocharis entedonoides (Walker) & endo & Rizzo \& Massa 2002 & Italy \\
\hline Chrysocharis gemma (Walker) & endo & Rizzo \& Massa 2002 & Italy \\
\hline Chrysocharis nephereus (Walker) & endo & Rizzo \& Massa 2002 & Italy \\
\hline Chrysocharis orbicularis (Nees) & endo & Rizzo \& Massa 2002 & Italy \\
\hline Diglyphus minoeus (Walker) & ecto & Rizzo \& Massa 2002 & Italy \\
\hline Diglyphus poppoea Walker & ecto & $\begin{array}{l}\text { Rizzo \& Massa } 2002 \\
\text { Yefremova et al. } 2011\end{array}$ & $\begin{array}{l}\text { Italy } \\
\text { Turkey }\end{array}$ \\
\hline Hemiptarsenus ornatus (Nees) & ecto & $\begin{array}{l}\text { del Bene } 1989 \\
\text { Rizzo \& Massa } 2002\end{array}$ & $\begin{array}{l}\text { Italy } \\
\text { Italy }\end{array}$ \\
\hline Neochrysocharis formosus (Westwood) & endo & $\begin{array}{l}\text { del Bene } 1989 \\
\text { Rizzo \& Massa } 2002\end{array}$ & $\begin{array}{l}\text { Italy } \\
\text { Italy }\end{array}$ \\
\hline Omphale stigma Goureau & endo & Goureau 1851 & France \\
\hline Pnigalio soemius Walker & ecto & $\begin{array}{l}\text { Bouček \& Askew } 1968 \\
\text { Hansson } 1985\end{array}$ & $\begin{array}{l}\text { Europe } \\
\text { Sweden }\end{array}$ \\
\hline Pnigalio incompletus Bouček & ecto & Rizzo \& Massa 2002 & Italy \\
\hline Pediobius metallicus (Nees) & endo & $\begin{array}{l}\text { del Bene } 1989 \\
\text { Bouček } 1965 \\
\text { Rizzo \& Massa } 2002 \\
\text { Civelek } 2002 \\
\text { Gençer } 2005\end{array}$ & $\begin{array}{l}\text { Italy } \\
\text { Europe } \\
\text { Italy } \\
\text { Turkey } \\
\text { Turkey }\end{array}$ \\
\hline Semielacher petiolata Girault & ecto & $\begin{array}{l}\text { Massa et al., } 2001 \\
\text { Rizzo \& Massa } 2002\end{array}$ & $\begin{array}{l}\text { Italy } \\
\text { Italy }\end{array}$ \\
\hline Zagrammosoma variegatum (Masi) & ecto & Rizzo \& Massa 2002 & Italy \\
\hline
\end{tabular}

(Hansson 1985), for Pediobius (Bouček 1965), and for other species according to the key for the European part of Russia (Triapitsyn 1978) and the Far East of Russia (Storozheva et al. 1995).
A standard statistical method was used for analysis of the data. The two-way hierarchical clustering analysis with paired group was applied in order to estimate preference of parasitoids for particular plants. 


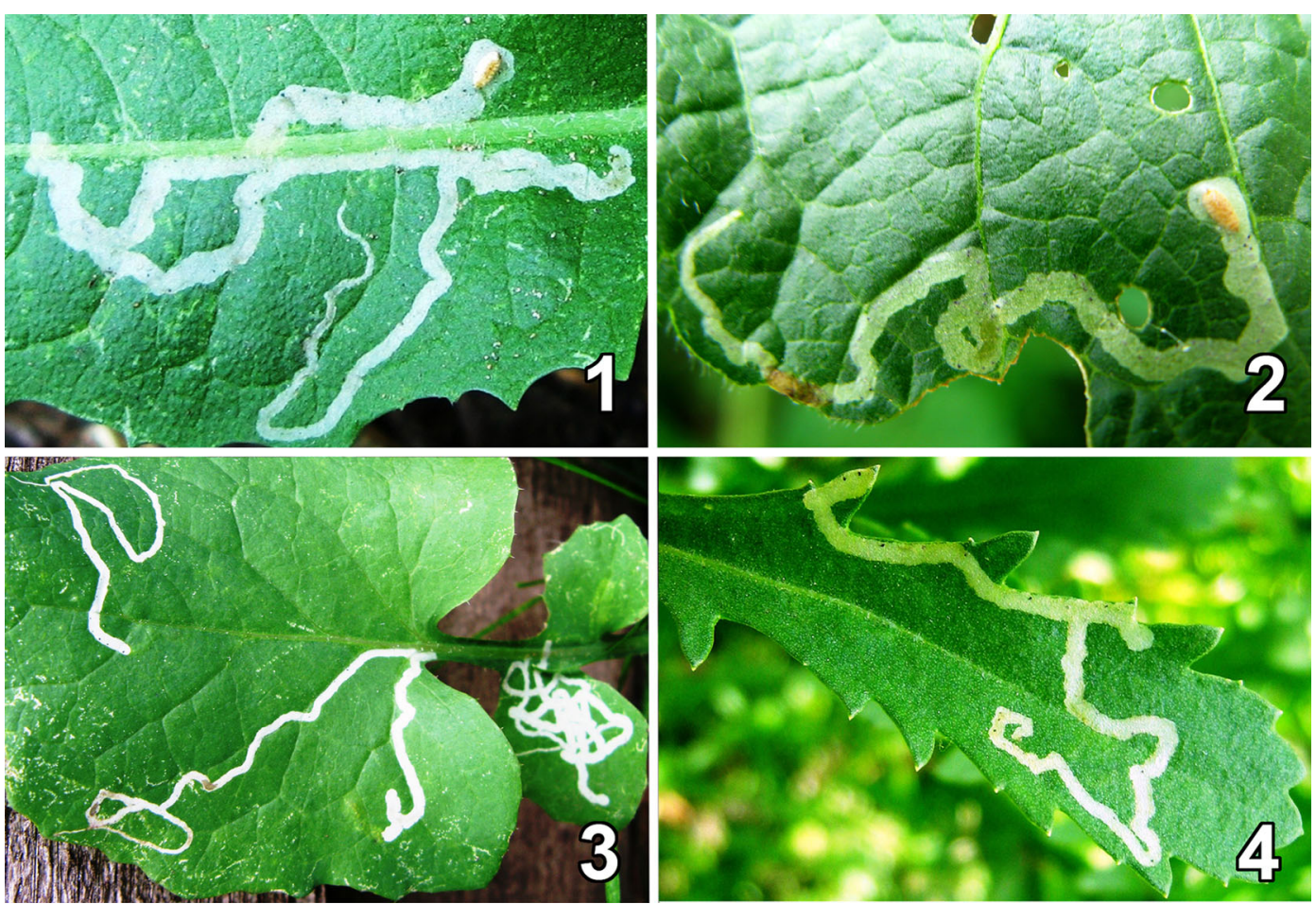

Figs. 1-4 Mines of Chromatomyia horticola on leaves of different host-plants: 1. Mine with puparium on Taraxacum officinale; 2. Mine with puparium on Alcea rosea; 3. Three linear mines and one serpentine mine on Lactuca tatarica; 4 . Mine on Leucanthemum vulgare

Similarities between objects were measured using the Gower Similarity Coefficient.

The material is deposited in the Zoological Institute, Russian Academy of Sciences, St. Petersburg, Russia) (ZISP).

\section{Results}

A total of 353 leaves with 379 mines were collected from 14 plant species belonging to three families: Asteraceae, Brassicaceae and Malvaceae. Most leaves housed only one mine; only 26 of the 353 leaves $(6.8 \%)$ contained two mines.

The available data allow assessment of whether the species composition of the reared parasitoids is representative of the true species richness in the study area. The number of collected leaves per species of plant and the number of parasitoid species hatched from these samples is a classic example of the number of species collected and the number of samples taken (Magurran 2004). Here $90 \%$ of the parasitoid species were already represented in the first $102.4 \pm 12.7$ leaves, which is far less than the total of 353 leaves collected in our research.

A total of 38 specimens of C. horticola and 349 specimens of eulophids were reared. Altogether, the revealed species assemblage comprises 16 Eulophidae species belonging to seven genera and three subfamilies (Eulophinae, Entedoninae and Tetrastichinae). The number of specimens of each species is listed in Table 2. Seven species (Chrysocharis viridis, C. trifasciatus, D. pusztensis, M. frontalis, $N$. aratus, $P$. cassidae, and $P$. pectinicornis) are new parasitoid records for C. horticola.

The number of specimens per species varied widely. Two dominant species, D. isaea (89 specimens) and P. metallicus (82 specimens), comprised about half ( $49 \%$ ) of the total number of captured specimens, while fewer than ten specimens were found for many other species.

The collected parasitoids were subdivided into two ecologically different groups. Larvae of ectoparasitoids develop on the body of the host (externally), while 


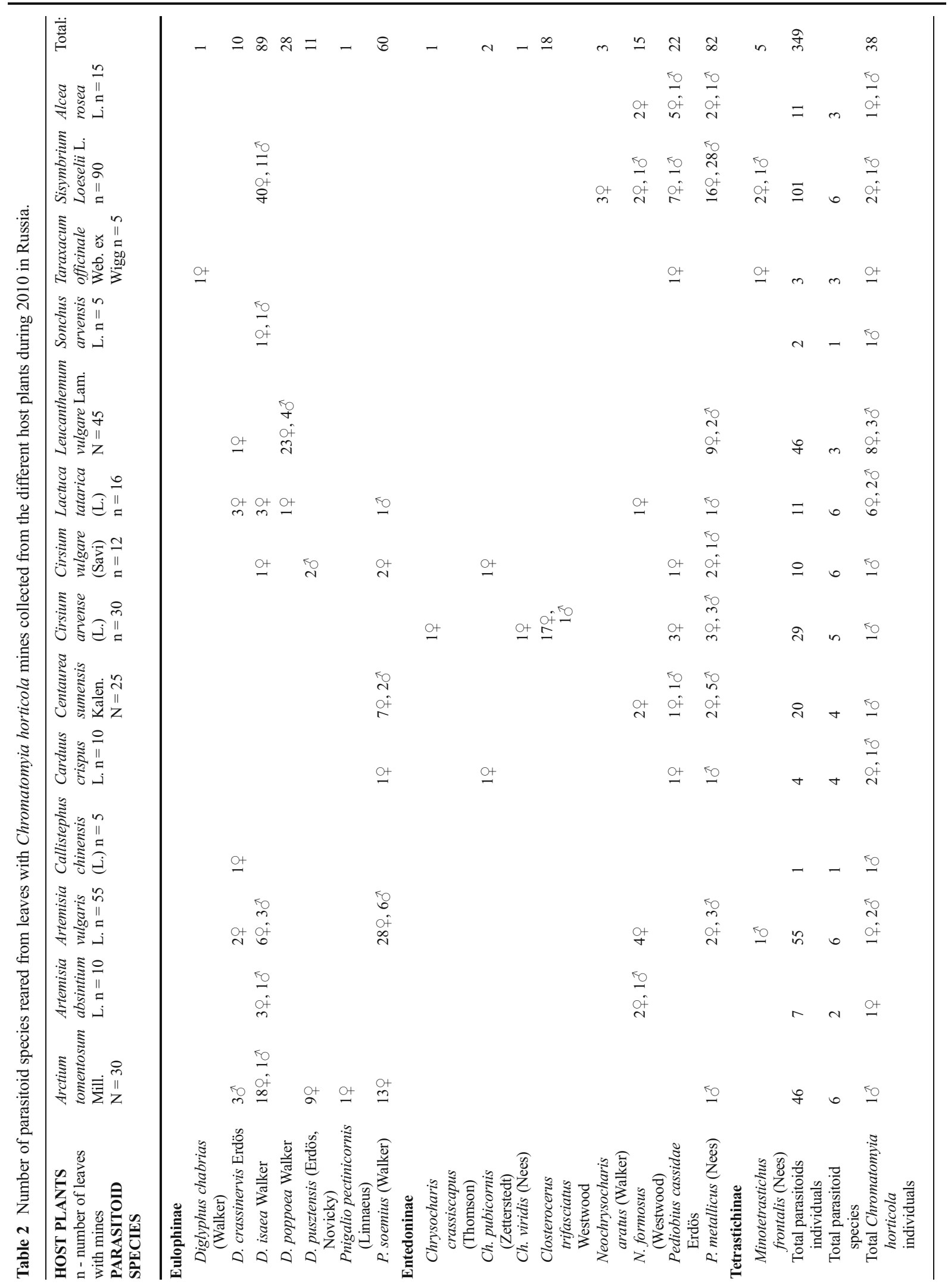



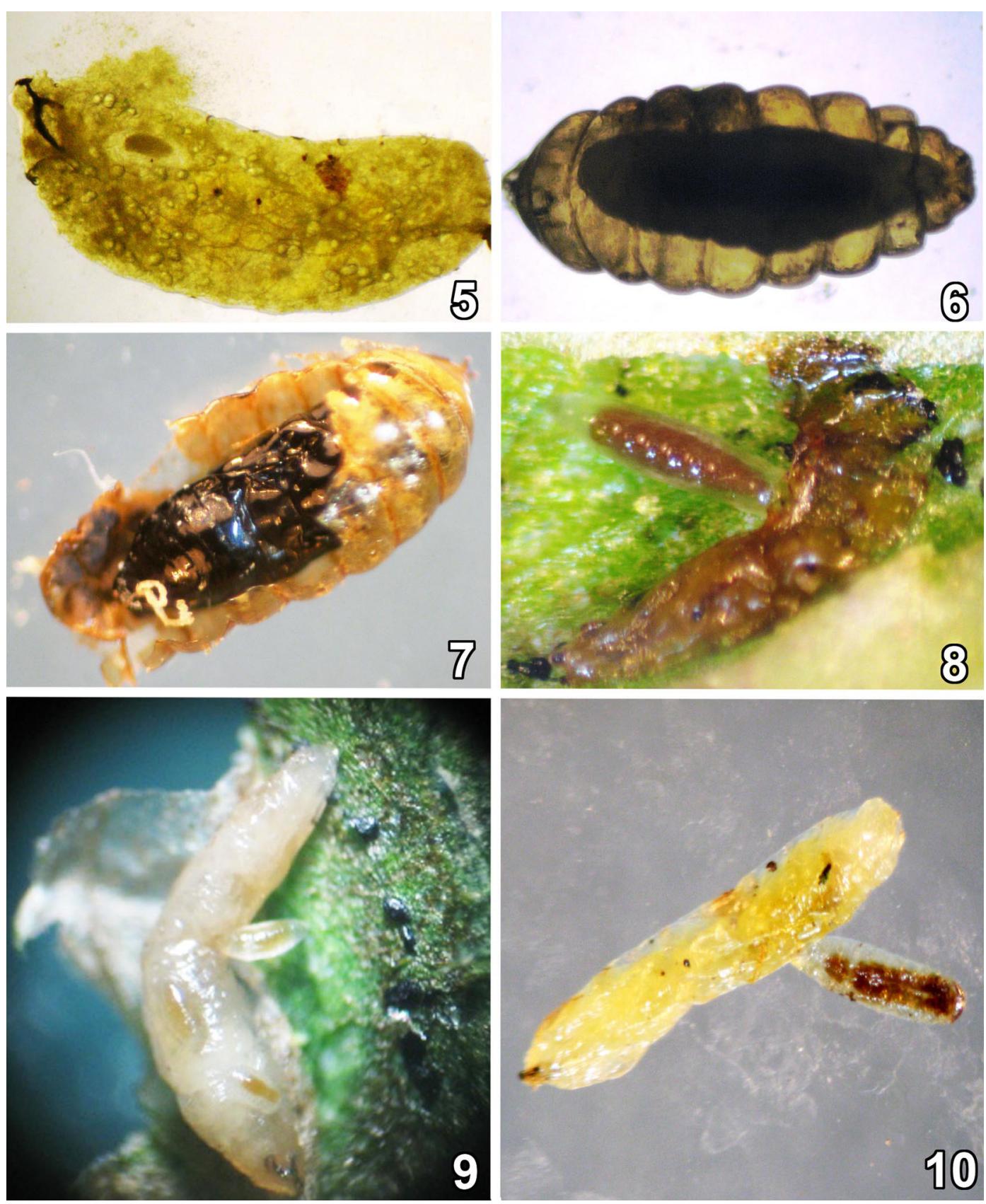

Figs. 5-10 Development of parasitoids on/in larva/pupa of Chromatomyia horticola: 5. Larva of $C$. horticola with first instar endoparasitoid larva of Chrysocharis sp. on Leucanthemum vulgare, 6. Puparium of $C$. horticola with last instar larva of Pediobius metallicus on Artemisia vulgare, 7. Puparium of C. horticola with endoparasitoid pupa of Pediobius metallicus

larvae of endoparasitoids develop inside the host. Some of the pre-imaginal stages of both dominant (ecto- and endoparasitoid) species are shown in Figures 5-10. A fully developed endoparasitoid is almost equal in size to

on Artemisia vulgare, 8. Ectoparasitoid larvae of Diglyphus sp. on larva of $C$. horticola and endoparasitoid inside body on Artemisia vulgaris, 9. Three Diglyphus crassinervis larvae of different ages on larva of C. horticola on Callistephus chinensis, 10. Ectoparasitoid larva of Diglyphus sp. on larva of C. horticola removed from mine of Leucanthemum vulgare

that of the host and occupies almost the entire volume of the body of its host except for the head capsule. In contrast, ectoparasitoids are always smaller than their host. Although several conspecific ectoparasitoids at 
different developmental stages might feed together on the body of a dipterous larva without competitive behavior, the competitive presence of two parasitoid species on or in the body of a host larva has also occasionally been observed.

Ectoparasitoids were represented in our species assemblage by genera belonging to the Eulophinae and Tetrastichinae, with eight species and 205 specimens (58.7\% of total). Endoparasitoids were represented by genera of the Entedoninae, with eight species and 144 specimens $(41.3 \%)$.

The majority of the parasitoid specimens $(88.5 \%)$ emerged in June and July. The number of ecto- and endoparasitoids in this period was similar, around 50\% $\pm 12 \%$ each. However, the sex ratio within these groups differed: in ectoparasitoids there were 4.2-fold and 4.4fold more females than males in June and July, respectively, whereas for endoparasitoids these values were only 1.2 -fold and 1.5 -fold.

For example, the dominant species, D. isaea, was characterized by $3-5$-fold more females than males in summer: in June the ratio was $38 q / 11 \hat{\jmath}$, and in July $32+/ 6 \AA$. In the dominant endoparasitoid, P. metallicus, males outnumbered females by $25 \delta / 18 q$ in June and by $16 \hat{\jmath} / 14 q$ in July. In other words, 1.3-fold and 1.1fold more males emerged than females (Fig. 11). These differences in sex ratio between the ecto- and endoparasitoids were probably not related to the plant species. On the small tumble-mustard (Sisymbrium loeselii), a plant of the cabbage family, the ratio for $D$. isaea in June was $26 \phi / 6 \hat{\sigma}$ and in July $14+/ 5 \hat{\jmath}$, whereas for $P$. metallicus in June it was $6 q / 15 \delta$ and in July 10 q $/ 13 \hat{\jmath}$.

To determine whether ecto- and endoparasitoids preferred a particular species of plant, eight parasitoid species with more than ten emerged specimens were chosen. According to their preference for a particular host plant, the parasitoids were divided into two main branches, separated at the 0.6 level of Gower distance (Fig. 12). Species composition between these branches separated into the ecto- and endoparasitoids. One branch contains the endoparasitoids ( $N$. formosus, $C$. trifasciatus, $P$. cassidae, $P$. metallicus), and the other the ectoparasitoids (P. soemius, D. isaea, D. poppoea, D. pusztensis). These two branches cover different ranges of plants. Endoparasitoids were found on all collected species of plants, while ectoparasitoids were apparently limited to only about half of them: namely, A. tomentosum, A. vulgaris, C. vulgare, L. tatarica, and C. sumensi.

\section{Discussion}

More than 21 species of eulophids (12 ecto- and nine endoparasitoids) are known as parasitoids of C. horticola in Europe (see Introduction). Of these, only 11 species were included in this study. In contrast to previous studies, we omitted species of the genera Cirrospilus and Semielacher because species of Cirrospilus have never been reared from C. horticola in the Middle Volga Region and species of Semielacher are not known at all from Russia (Yefremova 2002). Omphale stigma, which was reared in France 162 years ago (Goureau 1851) but never again, was also omitted from the list. The species Pnigalio soemius is considered a valid parasitoid of $C$. horticola and was reared from C. horticola in our study as well as in other studies (e.g. Bouček \& Askew 1968). In contrast to these results, Gebiola et al. (2012) reared this species from
Fig. 11 Sex ratio in the ectoparsitoid Diglyphus isaea and the endopasitoid Pediobius metallicus throughout the 2010 summer season in Russia

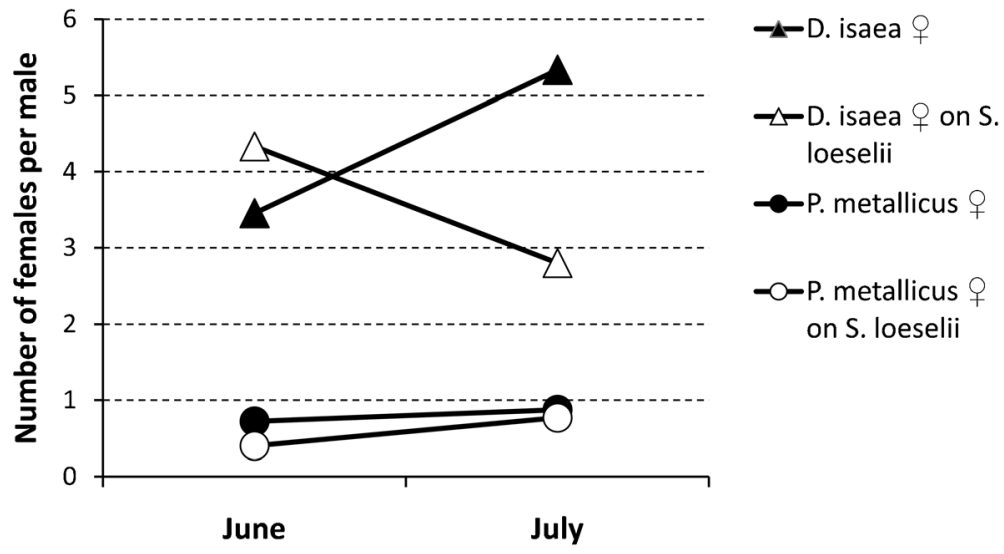


Fig. 12 Two-way clustering preference of parasitoids for particular plants. Similarity measured by Gower Similarity Coefficient; algorithm is paired group. Data transformed to presence $(1)$, absence $(0=$ empty cell). lepidopterous hosts and considered it a cryptic species. Neochrysocharis formosus is also accepted as a valid species, as confirmed by molecular investigation by Tetsuya et al. (2011).

The dominant species of the parasitoid complex of Chromatomyia fuscula Zetterstedt was Diglyphus begini (Ashmead) (Hågvar et al. 2000) and of Agromyza frontella (Rondani) - Diglyphus species (Coote \& Ellis 1986); consequently it is an ectoparasitoid species. Heinz \& Parrella (1990) showed for D. begini that females oviposit "female-eggs" on a large host of Liriomyza trifoli (Burgess), while "male-eggs" are oviposited on smaller hosts. The size of the host larvae was not measured in our study, but the number of females was usually $3-5$-fold greater than that of males.

Pediobius metallicus was not a common species in the parasitoid complex of C. fuscula (Hågvar et al. 1998) and it is mentioned in our study for the first time

\begin{tabular}{|c|c|c|c|c|c|c|c|}
\hline & & & & 1 & 1 & 1 & 1 \\
\hline 1 & 1 & & 1 & 1 & 1 & & \\
\hline & 1 & 1 & 1 & 1 & 1 & & 1 \\
\hline 1 & & & 1 & 1 & 1 & 1 & \\
\hline 1 & 1 & 1 & 1 & 1 & 1 & & \\
\hline 1 & 1 & 1 & 1 & & & & \\
\hline & & 1 & 1 & & & & \\
\hline & 1 & & 1 & & & & \\
\hline 1 & & 1 & 1 & & & & \\
\hline
\end{tabular}

Species of plants:

A. tomentosum

A. vulgaris

C. vulgare

L. tatarica

C. sumensis

S. loeselii

C. arvense

L. vulgare

A. rosea

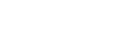

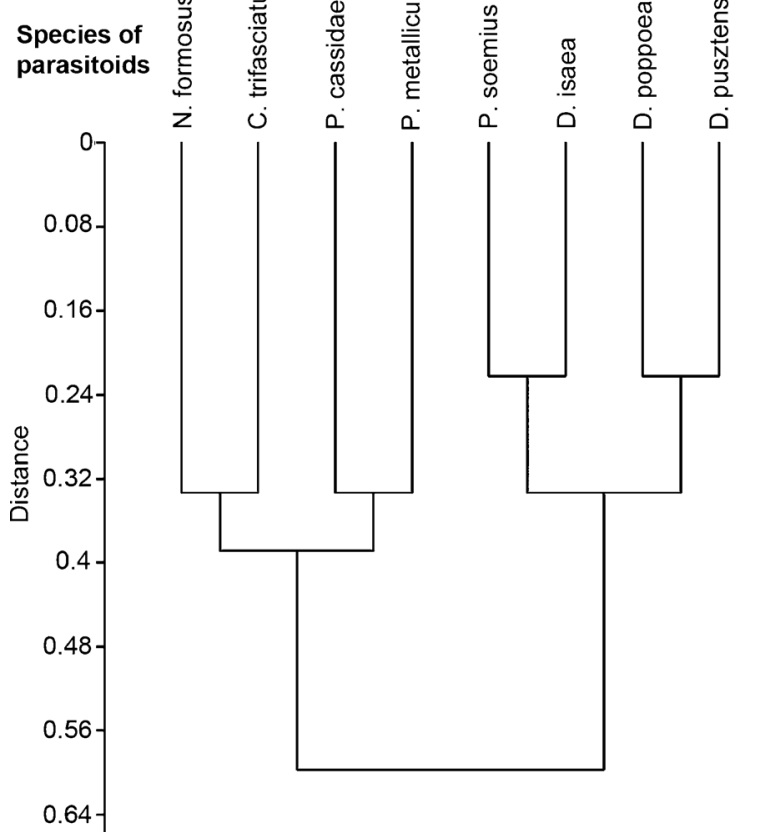

as a dominant species of Chromatomyia spp. in general. The sex ratio in the genus Pediobius observed for $P$. foveolatus reared from Cocinellidae, was revealed as $1 \widehat{\delta}: 1.33$ ㅇ for field-collected parasitoids and $1 \delta^{\lambda}: 6.75$ for laboratory-reared ones, with an average ratio of $1 \delta: 3.29$ (Stevens et al. 1977). In our study the sex ratio of $P$. metallicus was $1.3 \hat{O}: 1$. The sex ratio of $P$. metallicus reared from C. horticola is presented for the first time.

The terms idiobionts and koinobionts as understood by Askew \& Shaw (1986), are not included in this paper because these species of Eulophidae (in our list of the parasitoid complex of $C$. horticola) coincides with the concepts ecto- and endoparasitoids. The differences in the association of the ecto- and endoparasitoids with particular species of plants probably derive from the sensitivity of parasitoid larvae to environmental factors. Endoparasitoids develop inside the bodies of their host 
larvae and are therefore protected by the homeostasis of the larvae from the influence of environmental conditions; whereas ectoparasitoid larvae develop outside the host's body, thus being more exposed to the influence of environmental factors.

The dominant species Diglyphus isaea, like D. begini (Hågvar et al. 2000), is a very important regulating species and is widely used as an agent against agromyzid leaf miner pests in biological control programs. The species $P$. metallicus may also be considered in future as an agent against leaf miner pests.

Acknowledgments We thank Prof. Amnon Freidberg (Tel Aviv University, Israel) for his comments and Naomi Paz (Tel-Aviv University, Israel) for editorial assistance, as well as three anonymous reviewers for their critical comments.

Open Access This article is distributed under the terms of the Creative Commons Attribution License which permits any use, distribution, and reproduction in any medium, provided the original author(s) and the source are credited.

\section{References}

Allen, P. (1958). Larval morphology of different genera of Agromyzidae (Diptera). Proceedings of the Royal Entomological Society of London (Series A), 33, 123-135.

Anon. (1987). Chromatomyia horticola (Goureau) [Diptera: Agromyzidae], Garden pea leafminer, attacks legumes, Brassica spp., cucurbits, Compositae. Distribution Maps of Pests, Series A (Agricultural), 374 (revised): map +2 pp. London, UK: CAB International Institute of Entomology.

Askew, R. R., \& Shaw, M. R. (1986). In: J. Waage, \& D. Greathead (Eds.): Insect Parasitoids. 13th Symposium of the Royal Entomological Society of London (1985) pp. 225-264. London, UK: Academic Press.

Benavent-Corai, J., Martinez, M., \& Jiménez-Peydró, R. (2005). Catalogue of the host-plants of the world: Agromyzidae (Diptera). Bolletino di Zoologia Agraria e di Bachicoltura. Serie II, 37, 1-97.

Bouček, Z. (1965). Studies of European Eulophidae, IV: Pediobius Walk. and two allied genera (Hymenoptera). Acta Entomologica Musei Nationalis Pragae, 36, 5-90.

Bouček, Z., \& Askew, R. R. (1968). Index of palearctic Eulophidae (excl. Tetrastichinae) Index of Entomophagous Insects, 3 (Eds: Delucchi, V.; Remaudière, G.), Paris, France: Le François.

Civelek, H. S. (2002). Chromatomyia horticola (Goureau, 1851) (Diptera: Agromyzidae) parazitoit faunası için yeni bir kayıt: Pediobius metallicus (Nees, 1834) (Hymenoptera: Eulophidae)[A new record for the parasitoid fauna of Chromatomyia horticola (Goureau, (Diptera: Agromyzidae): Pediobius metallicus (Nees, 1834) (Hymenoptera: Eulophidae)]. Türkiye Entomoloji Dergisi, 26, 155-159 (in Turkish).
Cohen, M. (1936). The biology of the chrysanthemum leaf-miner, Phytomyza atricornis Mg. (Diptera: Agromyzidae). Annals of Applied Biology, 23, 612-632.

Coote, L. D., \& Ellis, C. R. (1986). Parasites of the alfalfa blotch leafminer, Agromyza frontella (Diptera: Agromyzidae) near Guelph, Ontario. Proceedings of the Entomological Society of Ontario, 117, 21-27.

del Bene, G. (1989). Nemici naturali di Liriomyza trifolii (Burgess), Chromatomyia horticola (Goureau) e Chromatomyia syngenesiae Hardy (Diptera, Agromyzidae) in Toscana. Redia, 72, 529-544.

del Bene, G., Gargani, E., \& Landi, S. (1993). Lotta biologica e integrata contro insetti dannosi alle piante da fiore e ornamentali: risultati preliminari. Colture Protette, 22(Suppl. 1), 13-18.

Dempewolf, M. (2006). Agromyzidae (Diptera) of economic importance. CD-ROM, Institute for Biodiversity and Ecosystem Dynamics, Zoological Museum of Amsterdam, the Netherlands. http://wbd.etibioinformatics.nl/bis/ agromyzidae.php

Erdös, J. (1958). Eulophidae in Hungaria recenter detectae. Acta Zoologica Academiae Scientiarum Hungaricae, 3, 211.

Gebiola, M., Gómez-Zurita, J., Monter, M. M., Navone, P., \& Bernardo, U. (2012). Integration of molecular, ecological, morphological and endosymbiont data for species delimitation within the Pnigalio soemius complex (Hymenoptera: Eulophidae). Molecular Ecology, 21, 1190-1208.

Gençer, L. (2005). Chalcidoid parasitoids of Chromatomyia horticola (Gour.) (Dip. Agromyzidae) in Sivas Province, Turkey. Journal of Pest Science, 78, 41-43.

Gençer, L. (2009). Contribution to the knowledge of the chalcid parasitoid complex (Hymenoptera: Chalcidoidea) of agromyzid leafminers (Diptera: Agromizidae) from Turkey, with new hosts and records. Journal of Plant Protection Research, 49, 1-159.

Goureau, C. C. (1851). Mémoire pour servir à l'histoire des Diptères dont les larves minent les feuilles des plantes et à celle de leurs parasites. Annales de la Société Entomologique de France ser. 2, 9, 131-176.

Griffiths, G. C. D. (1967). Revision of the Phytomyza syngenesuiae group (Diptera, Agromyzidae), including species hitherto known as "Phytomyza atricornis Meigen". Stuttgarter Beiträge zur Naturkunde, 177, 1-28.

Hågvar, E. B., Hofsvang, T., Trandem, N., \& Grendstad Sæterbø, K. (1998). Six-year Malaise trapping of the leaf miner Chromatomyia fuscula (Diptera: Agromyzidae) and its chalcidoid parasitoid complex in a barley field and its boundary. European Journal of Entomology, 95, 529-543.

Hågvar, E. B., Trandem, N., \& Hofsvang, T. (2000). Phenology and sex ratio of the parasitoids of a cereal leaf miner Chromatomyia fuscula (Diptera: Agromyzidae). European Journal of Entomology, 97, 339-346.

Hansson, C. (1985). Taxonomy and biology of the Palaearctic species of Chrysocharis Förster, 1856 (Hymenoptera: Eulophidae). Entomologica Scandinavica (Suppl.), 26, 1130.

Heinz, K. M., \& Parrella, M. P. (1990). The influence of host size on sex ratios in the parasitoid Diglyphus begini (Hymenoptera: Eulophidae). Ecological Entomology, 15, 391-399. 
Ikeda, E. (1996). Revision of the Japanese species of Chrysocharis (Hymenoptera, Eulophidae), III. Japanese Journal of Entomology, 64, 551-569.

Kumar, A. (1985). Incidence of parasitism of Diglyphus isaea (Walk.) on Chromatomyia horticola (Gour.) a pest of Pisum sativum in northern India. Entomon, 10, 55-58.

Magurran, A. E. (2004). Measuring biological diversity. Oxford, UK: Blackwell Publishing.

Massa, B., Rizzo, M. C., \& Caleca, V. (2001). Natural alternative hosts of Eulophidae (Hymenoptera: Chalcidoidea) parasitoids of the citrus leafminer Phyllocnistis citrella Stainton (Lepidoptera: Gracillariidae) in the Mediterranean basin. Journal of Hymenoptera Research, 10, 91-100.

Melis, A. (1935). Contributo alla conoscenza morfologica e biologica della Phytomyza atricornis Meig. Redia, 21, 205262.

Raj, D., Devi, N., \& Chandel, Y. S. (1995). Infestation of leaf miner, Chromatomyia horticola Goureau on Brassica campestris in mid hill zone of Himachal Pradesh (India). Journal of Entomological Research, 19, 107-110.

Rizzo, M. C., \& Massa, B. (2002). Ecology of the eulophid parasitoid community living on hosts of spontaneous flora linked to citrus grove (Hymenoptera: Chalcidoidea: Eulophidae). In G. Melika \& C. Thuróczy (Eds.), Parasitic wasps: evolution, systematics, biodiversity and biological control. International symposium: "Parasitic Hymenoptera: Taxonomy and Biological Control" (2001, Köszeg, Hungary) (pp. 351-361). Budapest, Hungary: Agroinform Kiadó \& Nyomda.

Rizzo, M. C., \& Massa, B. (2004). Fenologia dei parassitoidi (Hymenoptera, Eulophidae) di fillominatori della flora spontana). In: Atti XIX Congresso nazionale italiano di Entomologia, Catania (2002). Vol. 1-2: pp. 491-495. Sondrio, Italy: Litografia Tipografia Polaris.

Spencer, K. A. (1973). Agromyzidae (Diptera) of economic importance (Series Entomologica, Vol. 9). The Hague, the Netherlands: Dr. W. Junk.

Spencer, K. A. (1976). The Agromyzidae (Diptera) of Fennoscandia and Denmark. Fauna Entomologica Scandinavica, 5, pp. 107, 304, 492. Klampenborg, Denmark: Scandinavian Science Press.

Spencer, K. A. (1989). Family Agromyzidae. In: N. L. Evenhuis [Ed.]. Catalog of the Diptera of the Australasian and Oceanian regions. Bishop Museum Special Publications, 86, 538-547. Honolulu, Hawaii.

Spencer, K. A. (1990). Host specialization in the world: Agromyzidae (Diptera). pp. 394, 396, 397. Dordrecht, the Netherlands: Kluwer Academic Publishers.

Stevens, L. M., McGuire, J. U., Steinhauer, A. L., \& Zungoli, P. A. (1977). The observed sex ratio of Pediobius flovealatus (Hym.: Eulophidea) in field populations of Epilachna vamvestis (Col.: Coccinellidae). Entomophaga, 22, 175-177.
Storozheva, N. A., Kostjukov, V. V., \& Yefremova, Z. A. (1995). 46. Family Eulophidae, Subfamily Eulophinae. In: P. A. Lera (Ed.). [Key to the insects of Russian Far East in six volumes]. 4, pp. 346-505. Vladivostok, Russia: Dal'nauka. [In Russian]

Strakhova, I. S., Yefremova, Z. A., von Tschirnhaus, M., \& Yegorenkova, E. N. (2013). Parasitoid complex (Hymenoptera: Eulophidae) of mining flies (Diptera, Agromyzidae) in the Middle Volga River Basin. Zoologicheskii Zhurnal, 92, 553-561.

Tetsuya, A., Kazuki, M., \& Yoshihisa, A. (2011). Gene flow between sexual and asexual strains of parasitic wasps: a possible case of sympatric speciation caused by a parthenogenesis-inducing bacterium. Journal of Evolutionary Biology, 24, 1254-1262.

Triapitsyn, V. A. (1978). Hymenoptera II. Chalcidoidea, 13. Sem. Eulophidae - Evlofidy (excl. Tetrastichinae) In: G. S. Medvedev (Ed.), Opredelitel' Nasekomykh Evropey'skoy Chasti SSSR, Tom III, Pereponchatokrylye, Vtoraya [=2nd] chast'. pp. 381-467. Leningrad, Russia: Nauka [in Russian].

Vidal, S. [Ed.] (1997). Determination list of entomophagous insects. No. 13. Bulletin. Section Regionale Ouest Palaearctique, Organisation Internationale de Lutte Biologique, 20.

von Tschirnhaus, M. (1969). Zur Kenntnis der Variabilität, Eidonomie und Verwandtschaft bemerkenswerter Agromyzidae (Diptera). Senckenbergiana Biologica, 50, 143-157.

Winkler, I. S., Scheffer, S. J., \& Mitter, C. S. (2009). Molecular phylogeny and systematics of leaf-mining flies (Diptera: Agromyzidae): delimitation of Phytomyza Fallén sensu lato and included species groups, with new insights on morphological and host-use evolution. Systematic Entomology, 34, 260-292.

Yefremova, Z. A. (2002). Catalogue of the Eulophidae (Hymenoptera) of Russia. Linzer Biologische Beiträge, 34, 563-618.

Yefremova, Z. A., Civelek, H. S., Boyadzhiyev, P., Dursun, O., \& Eskin, A. (2011). A review of Turkish Diglyphus Walker (Hymenoptera, Eulophidae), with description of a new species. Annales de la Société Entomologique de France, 47, 273-279.

Yefremova, Z. A., \& Shroll, O. J. (1996). An account of the European species of Diglyphus (Hymenoptera: Eulophidae). Entomologicheskoe Obozrenie, 75(426-437), 483 (in Russian).

Yefremova, Z. A., Strakhova, I. S., Yegorenkova, E. N., \& Kravchenko, V. D. (2012). A study of parasitoids (Hymenoptera, Eulophidae) leaf mining fly Chromatomyia horticola (Goureau) (Diptera: Agromyzidae) to spontaneous grass vegetation in the Ulyanovsk province. XIV Congress of Russian Entomological Society (St. Petersburg, Russia, p. 147). 